\title{
The end of the American Dream?
}

The stock-market crash of the past two weeks signals the end of more than a mere bull-market. Even if governments have the wit to avoid a serious depression, United States citizens will be impoverished.

THE crash on the world's stock markets in the past two weeks seems to have brought out the worst in people who should have known better. There seems to have been a competition to emulate President Theodore Roosevelt's fatuities on the similar events of 1929: President Ronald Reagan's description, two weeks ago, of the slump in stock prices as a "readjustment" has now been echoed by the president of the British Confederation of British Industry. Stock-market managers have also been blaming their machinery for their misfortunes. Thus the New York Stock Exchange has been pleading with its traders not to let their computers generate orders to sell stocks, but to do the job manually instead. There has also been an outburst of indignation at the use of the world's markets in the future prices of stocks as a means of insuring against rapid changes in the value of publicly traded stocks. Are the stock markets really saying that there would have been no crash if their customers had been less able to act quickly, and denied the hope of protecting themselves against loss?

The temptation should be resisted to pretend that this wild talk, and the events to which it refers, concern only the inwardlooking community of those who deal in other people's money. The events of the past two weeks concern us all. First, there is the near-certainty that most of us will turn out to have lost money; the pension funds and insurance companies which have grown to be the big players on the world's stock markets represent the interests of broad sections of the world's free-market communities. Their losses in the past two weeks are everybody's losses. Moreover, there is no great substance in the argument that the losses are but paper losses, and that, because the financial institutions still between them own the same proportion of industrial assets as before the crash, nothing has been permanently lost. For one thing, those lucky enough to have turned their share of paper wealth into cash before the crash (perhaps because they had quit working) have benefited at the expense of others. More important, the prices being paid for stocks (and thus, indirectly, for the productive assets they represent) will quickly be discovered to have been uneconomically high. The problem is especially serious in the United States, where even a successful navigation of the troubles ahead will require important and painful shifts in the pattern of the US economy.

\section{Recession}

The second danger is that matters will be made worse than they are already by a serious economic recession, perhaps even by a slump along the lines of the 1930s. There is nothing remarkable in this observation; indeed, the way in which central banks in Western Europe and the United States have been reducing interest rates, while a necessary response to the plight of the stock markets, shows that the authorities are also aware of the more distant danger. But there are limits to what governments can do. After the crash, people will think themselves less wealthy than they were before (which will be literally true for those wishing to turn their stock-market assets into cash or other kinds of assets, such as dwellings), and so will spend less, reducing the demand for goods and services. Only time will tell how important this effect will be, but the assumption so far that rates of economic growth will be reduced by a third or thereabouts could be wildly optimistic. Events may yet show that, left to themselves, growth rates could become negative.

Free-market governments all know what should be done when there is a prospect of recession. This is when Keynes comes into his own. Governments should spend more, or alternatively reduce taxes, so that the demand for goods and services is increased, and should be unafraid of temporarily running their own budgets at a deficit. The embarrassment, in the United States, is that the government took precisely those steps seven years ahead of time - and for the past three years has been trying vainly to reduce the deficit to more manageable proportions. Only last week, President Reagan offered the US Congress negotiations on a strategy eventually to win a balanced budget. In logic, he could have said that this is not when the US government should be drawing in its horns. But the accumulated deficits of the past several years, and the present fear that the US government has lost control of fiscal affairs, leave no room for manoeuvre. If the deficit were allowed actually to grow, it could not be financed as in the past few years by overseas investment in the United States, but only by printing the missing money. The United States is boxed in between inflation and recession.

The way out must be painful. The counterpart of the domestic budget deficit is the adverse external trade balance, which in August exceeded $\$ 15,000$ million, roughly the equivalent of $\$ 60$ for every US citizen in that month alone. The chances are that, with the precipitous fall of the dollar against most other currencies in the past ten days, the trade balance will have been corrected, which will mean that US citizens will feel (and be) $\$ 60$ a month worse off. The problem for the future is that of paying off the accumulated debts without the pursuit of protectionist policies (which could also precipitate a depression). That means that the trade balance must be turned round, requiring first enough savings from people's income to sustain fresh investment in manufacturing plant and then a steady stream of exports. The result will be a transfer of personal prosperity from the United States to its trading partners. That dismal prospect is the best possible outcome from the present box.

Do governments have the will and the means to plot such a course? The record is not encouraging. Most recently, sensing that the imbalances were getting out of hand, governments and central banks joined forces to prevent what has since happened - a further substantial fall in the value of the US dollar. That should have been a warning to those concerned that events had escaped from their control. It is worrying that the warning seemed ineffective, and does not promise well for the difficult months ahead, when all free-market governments will have to strike a judicious balance between firm and free economic policy. With a presidential election in the offing, the US government will need particularly strong nerves to superintend what is bound to seem the impoverishment of the United States. The task will be especially difficult because even the wisest and most courageous policies may be defeated by bad luck - the failure of a major financial institution or the bankruptcy of a major debtor among the developing countries. Yet the alternative is worse. 